\title{
Batasan Penerapan Asas Persidangan Terbuka untuk Umum dalam Siaran Persidangan Pidana oleh Media
}

\author{
Kamri Ahmad dan Hardianto Djanggih \\ Fakultas Hukum Universitas Muslim Indonesia Makassar \\ Jln. Urip Sumoharjo, Km 5 Makassar, Sulawesi Selata \\ Fakultas Hukum Universitas Tompotika Luwuk Sulawesi Tengah \\ Jln. Dewi Sartika No. 65 Luwuk Sulawesi Tengah 94715 \\ kamriah@yahoo.com; hardianto_djanggih@yahoo.co.id
}

Received: 22 September 2017; Accepted: 8 Desember 2017; Published: 28 Februari 2018

DOI: 10.20885/iustum.vol24.iss3.art8

\begin{abstract}
This research discussed, firstly, whether live broadcasting of criminal justice processes is in line with legislative approaches? Secondly, what are the limits of open court principles, particularly in relation to broadcasting by media? This research was a juridical-normative research. The results showed that, first, live broadcasting is not explicitly prohibited in the regulation on broadcasting provided that it is done in accordance with the ethics of broadcasting and journalism. However, live broadcasting of trial processes shall be limited so as to not disturb the courts of justice and the rights of the accused, witnesses and victims as stated in the Criminal Procedure Code (KUHAP), the Law on the Protection of witnesses and victims as well as any other relevant laws and regulations. Second, live broadcasting of criminal justice processes by the media in accordance with open court principles shall still be limited. This regards the fact that the application of the open court principle shall always respect the principle of presumption of innocence and prevent trial by the press in order to uphold the principles of fair trial.
\end{abstract}

Keywords: Criminal Justice; Live Broadcasting; Trial Process

\section{Abstrak}

\begin{abstract}
Penelitian ini mengangkat permasalahan, pertama, siaran langsung proses peradilan pidana dalam pendekatan perundang-undangan, kedua, batasan asas persidangan terbuka untuk umum dalam konteks penyiaran oleh media. Penelitian ini merupakan penelitian yuridis-normatif. Hasil penelitian menyimpulkan, Pertama, proses siaran langsung tidak dilarang secara eksplisit dalam peraturan tentang penyiaran sepanjang sesuai dengan etika penyiaran dan jurnalistik. Namun demikian, penyiaran langsung proses sidang tetap harus agar tidak menciderai marwah pengadilan serta hak-hak terdakwa, saksi maupun korban sebagaimana diatur dalam KUHAP, UU Perlindungan saksi dan korban serta peraturan perundang-undangan terkait. Kedua; siaran langsung proses peradilan pidana oleh media yang sejalan dengan asas persidangan terbuka untuk umum, tetap harus dibatasi. Karena penerapan asas persidangan terbuka untuk umum harus tetap menghormati asas praduga tak bersalah dan menghindari trial by press untuk menegakkan prinsip peradilan yang adil dan tidak berpihak (fair trial).
\end{abstract}

Kata-kata Kunci: Peradilan Pidana, Siaran Langsung, Proses Persidangan 


\section{Pendahuluan}

Media televisi di Indonesia menjadi media dengan konsumen terbesar dibanding jenis media lainnya (cetak, radio dan interaktif/internet). ${ }^{1}$ Kehadiran media televisi terhadap tayangan yang disajikan memberi pengaruh yang besar bagi konsumen media. ${ }^{2}$ Media televisi dinilai mempunyai kelebihan dapat menyajikan siaran secara langsung dengan berbagai macam siaran. ${ }^{3}$

Dimmick \& Rothenbuhler mengemukakan bahwa ada tiga sumber kehidupan bagi media, yaitu content, capital dan audiences. Content terkait dengan isi dari sajian media, misalnya program acara (televisi dan radio), berita/feature, dan lain sebagainya. Capital menyangkut sumber dana untuk menghidupi media. Sedangkan audience terkait dengan masalah segmen yang dituju. Ketika media lebih mengedepankan konten dan penonton tentu sajian isi media sesuai dengan konsep yang ideal. ${ }^{4}$

Media televisi yang fokus terhadap konten pemberitaan telah merambah dunia peradilan. Penyiaran kasus-kasus hukum dilakukan oleh media secara langsung maupun siaran tidak langsung (siaran ulang). Terkait hal tersebut Tim Peneliti Badan Pembinaan Hukum Nasional (BPHN) Kemenkumham RI ${ }^{5}$ telah melakukan penelitian terhadap praktek siaran langsung media televisi yang menemukan bahwa praktik courtroom television yang diartikan sebagai kegiatan yang menyiarkan baik secara langsung maupun ulang terhadap suatu kasus banyak menyudutkan pihak tersangka, hal ini tentunya melanggar asas presumption of innocent atau asas praduga tak bersalah. Praktek courtroom television dikhawatirkan akan mengarah kepada perbuatan trial by the press yang berpotensi menyebabkan contempt of court.

1 Rachmat Kriyantono, "Pemberdayaan Konsumen Televisi Melalui Ketrampilan Medialiteracy Dan Penegakan Regulasi Penyiaran" Jurnal Penelitian Komunikasi, Media Massa dan Teknologi Informasi, Volume 10, Nomor 2, 2017, hlm. 4

${ }^{2}$ Rachmat Kriyantono, Ibid., hlm. 6

${ }^{3}$ Feibe A. Kasengkang, "Kewenangan Komisi Penyiaran Indonesia Tentang Persyaratan Program Isi Siaran Menurur Undang-Undang Nomor 32 Tahun 2002", Jurnal Lex Privatum, Volume 5, Nomor 3, 2017, hlm. 76

${ }^{4}$ Machyudin Agung Harahap, "Kapitalisme Media; Ekonomi Politik Berita dan Diskursus Televisi", Aura Pustaka, Yogyakarta, 2013, hlm. 2

${ }^{5}$ Mosgan Situmorang dkk, "Penelitian Hukum tentang Pengaruh Praktir Courtroom Television Terhadap Independensi Peradilan", Badan Pembinaan Hukum nasional Kementrian Hukum dan HAM RI, 2013 dalam http://www.bphn.go.id/data/documents/laphir_integrasi_cetak.pdf 
Sepanjang 2017, dalam konteks penyiaran oleh media, kasus Ahok dan Jessica menarik untuk dikaji lebih dalam. Kedua kasus tersebut menjadi dasar penelitian ini. Kasus pembunuhan oleh Jessica dan kasus penistaan agama oleh Ahok menjadi sorotan publik dan proses sidangnya ditayangkan secara langsung. Bahkan, proses sidang disiarkan secara detil.

Siaran langsung proses sidang kedua kasus tersebut ternyata menjadi sorotan publik, bahkan dunia internasional yang menilai lembaga pengadilan Indonesia masih sangat buruk. ${ }^{6}$ Melalui siaran langsung tersebut dikhawatirkan akan menempatkan hakim sebagai pihak yang diadili oleh publik atas proses memeriksa, mengadili dan memutus perkara. Namun demikian, media tetap menjadi alat kontrol agar hakim tetap bersikap imparsial.

Penelitian ini akan membahas lebih jauh terkait posisi siaran langsung yang ditayangkan oleh media televisi dalam peraturan perundang-undangan dan asas persidangan terbuka untuk umum.

\section{Rumusan Masalah}

Tulisan ini difokuskan pada dua pokok permasalahan sebagai berikut. Pertama, apakah siaran langsung proses peradilan pidana melalui media televisi telah sesuai dengan peraturan perundang-undangan? Kedua, bagaimanakah batasan asas persidangan terbuka untuk umum dalam konteks penyiaran oleh media?

\section{Tujuan Penulisan}

Penelitian ini memiliki dua tujuan, pertama, mengkaji kesesuaian siaran langsung proses peradilan pidana melalui media televisi berdasarkan peraturan perundang-undangan yang berlaku. Kedua, mengkaji batasan asas persidangan terbuka untuk umum dalam konteks penyiaran oleh media.

\section{Metode Penelitian}

Penelitian ini merupakan penelitian hukum normatif, yaitu untuk menganalisa tentang sejauh manakah suatu peraturan atau perundang-undangan

\footnotetext{
${ }^{6}$ Mahrus Ali, "Sistem Peradilan Pidana Progresif; Alternatif Dalam Penegakan Hukum Pidana", Jurnal Ius Quia Iustum, Volume 14, Nomor 2, 2007, hlm. 211.
} 
atau hukum yang sedang berlaku secara efektif. Sumber data yang digunakan merupakan data skunder yang terdiri dari bahan hukum primer (peraturan perundang-undangan) dan bahan hukum skunder (kajian ahli, jurnal dan buku). Teknik pengumpulan data menggunakan studi pustaka. Data yang telah diperoleh dari bahan-bahan hukum kemudian dianalisis secara deskriptif-kualitatif.

\section{Hasil Penelitian dan Pembahasan}

\section{Siaran Langsung Proses Peradilan Pidana Menurut Ketentuan Perundang- Undangan}

Hakim adalah salah satu pejabat negara yang melaksanakan peradilan menurut peraturan perundang-undangan. Hakim diberi kewenangan dalam memutus dan menyelesaikan suatu perkara. Hal tersebut menunjukkan adanya kebebasan hakim sebagai pelaksana kekuasaan kehakiman.7K. Bertends mengatakan bahwa kebebasan hakim dalam mengadili, pada dasarnya bisa digolongkan pada pengertian kebebasan yuridis, sebagai kebebasan yang bersumber dari hak-hak manusia yang dijamin hukum. ${ }^{8}$

Fungsi utama dari seorang hakim adalah memberikan putusan terhadap perkara yang diajukan kepadanya. Mewujudkan putusan yang memenuhi rasa keadilan, hakim dituntut untuk dapat melaksanakan proses persidangan sesuai dengan ketentuan perundang-undangan. ${ }^{9}$ Salah satunya adalah pada pelaksanaan proses peradilan pidana yang terbuka untuk umum. Hal ini merupakan hak terdakwa, yakni hak untuk diadili di sidang pengadilan yang terbuka untuk umum. Hal ini sebagaimana diatur dalam Pasal 153 ayat (1) Undang-Undang Nomor 8 Tahun 1981 tentang Hukum Acara Pidana (KUHAP), bahwa,"Untuk keperluan pemeriksaan hakim ketua sidang membuka sidang dan menyatakan terbuka untuk umum kecuali dalam perkara mengenai kesusilaan atau terdakwanya anak-anak.".

7 Yusi Amdani, "Implikasi Penafsiran Undang-Undang Oleh Hakim Praperadilan Dalam Perkara Tindak Pidana Korupsi", Jurnal Mimbar Hukum, Volume 27, Nomor 2, 2015, hlm. 462

${ }_{8}$ Eri Sertyanegara, "Kebebasan Hakim Memutus Perkara Dalam Konteks Pancasila (Ditinjau Dari Keadilan "Substantf")", Jurnal Hukum dan Pembangunan, Volume 44, Nomor 4, 2013, hlm. 466

${ }^{9}$ Hardianto Janggih danYusuf Saefudin, "Pertimbangan Hakim pada Putusan Praperadilan: Studi Putusan Nomor: 09/PID. PRA/2016/PN. Lwk tentang Penghentian Penyidikan Tindak Pidana Politik Uang". Jurnal Penelitian Hukum De Jure, Volume 17, Nomor 3 (2013), hlm. 416. 
Pengaturan persidangan terbuka untuk umum tidak hanya diatur dalam KUHAP, Pasal 13 Undang-Undang Nomor 48 Tahun 2009 tentang Kekuasaan Kehakiman (UU No. 48 Tahun 2009) juga mengatur tentang persidangan terbuka untuk umum, yaitu:

1. Semua sidang pemeriksaan pengadilan adalah terbuka untuk umum, kecuali undang-undang menentukan lain.

2. Putusan pengadilan hanya sah dan mempunyai kekuatan hukum apabila diucapkan dalam sidang terbuka untuk umum.

3. Tidak dipenuhinya ketentuan sebagaimana dimaksud pada ayat (1) dan ayat (2) mengakibatkan putusan batal demi hukum.

Siaran langsung proses sidang kaitannya dengan asas persidangan terbuka untuk umum sesuai dengan Pasal 195 Kitab Undang-undang Hukum Acara Pidana (KUHAP) yang menyatakan bahwa semua putusan pengadilan hanya sah dan mempunyai kekuatan hukum apabila diucapkan di sidang terbuka untuk umum. Bagir Manan ${ }^{10}$ mengatakan bahwa putusan itu sekali diucapkan, maka menjadi milik publik. Karena diucapkan dalam sidang terbuka maka itu menjadi milik publik, tidak lagi milik dari mereka yang berperkara saja. Setiap mereka yang berkepentingan berhak untuk mengetahui putusan itu.

Penegasan Pasal 153 ayat (1), Pasal 195 KUHAP dan Pasal 13 ayat (1, 2 dan 3) UU No. 48 Tahun 2009 tentang Persidangan Terbuka untuk Umum, membuka ruang bagi industri media televisi untuk menghadiri proses persidangan dengan penayangan secara langsung.

Akan tetapi, di Indonesia sebetulnya belum terdapat aturan yang membolehkan maupun melarang siaran langsung media selama proses sidang di Pengadilan secara eksplisit dan detail, baik itu dalam KUHAP maupun di perundang-undangan lainnya. KUHAP hanya mengatur hakim sebagai pemelihara tata tertib persidangan, dapat mengeluarkan orang yang dianggap merendahkan martabat persidangan dari ruang sidang. Hal mana membuat hakim dapat saja mengusir juru kamera yang hadir di ruang sidang, apabila hal tersebut dianggap mengganggu proses persidangan.

\footnotetext{
${ }^{10}$ Putusan Pengadilan akan Terbuka untuk Umum http://www.hukumonline.com/berita/ $\mathrm{baca} /$ hol8500/putusan-pengadilan-akan-terbuka-untuk-umum diakses pada tanggal 3 Mei 2017
} 
Pengaturan mengenai perekaman sidang ditemukan dalam beberapa peraturan. Surat Edaran Mahkamah Agung (SEMA) No. 4 Tahun 2012 tentang Perekaman Proses Persidangan mengatur pelaksanaan persidangan yang lebih transparan, akuntabel dan teratur, maka selain catatan panitera pengganti yang tertuang dalam berita acara persidangan yang selama ini diatur dalam Pasal 202 ayat (1) KUHAP, ke depannya perlu dilakukan perekaman audio visual secara sistematis, teratur dan tidak terpisahkan dari prosedur tetap persidangan. Untuk kebutuhan tersebut, maka secara bertahap persidangan pada pengadilan tingkat pertama harus disertai rekaman audio visual dengan ketentuan sebagai berikut:

1. Hasil rekaman audio visual merupakan komplemen dari Berita Acara Persidangan;

2. Perekaman audio visual dilakukan secara sistematis dan terjamin integritasnya;

3. Hasil rekaman audio visual persidangan dikelola oleh kepaniteran, dan

4. Hasil rekaman audio visual sebagai bagian dari bundel A.

Untuk memastikan pemenuhan ketentuan di atas, maka prioritas pelaksanaan rekaman audio visual pada persidangan akan dilakukan sebagai berikut :

1. Untuk tahap awal dilakukan pada perkara-perkara Tindak Pidana Korupsi dan perkara lain yang menarik perhatian publik;

2. Ketua Pengadilan wajib memastikan terlaksananya perekaman audio visual sesuai dengan surat edaran ini.

Selain diperbolehkannya rekaman audio visual selama persidangan, siaran langsung diatur lebih lanjut dalam Undang-Undang No. 32 Tahun 2002 tentang Penyiaran dan dalam Pedoman Perilaku Penyiaran (P3) dan Standar Program Siaran (SPS) Komisi Penyiaran Indonesia (KPI) 2012. Penyiaran menurut UU Penyiaran mensyaratkan adanya pemancarluasan siaran dan diterima secara serentak oleh masyarakat. ${ }^{11}$ Sehingga, tidak hanya sebatas rekaman audio visual, melainkan adanya penyebarluasan melalui media. Sedangkan program siaran langsung atau siaran tidak langsung pada sidang pengadilan menurut Pasal 46 P3/SPS KPI 2012 boleh dilakukan, asalkan sesuai dengan ketentuan penggolongan

${ }^{11}$ Lihat Pasal 1 Angka 2 UU No. 32 Tahun 2002 tentang Penyiaran 
program siaran. Ketentuan penggolongan siaran didasarkan pada klasifikasi berdasarkan kelompok usia, dimana jam dan konten penyiaran disesuaikan dengan usia tertentu. ${ }^{12}$

Adapun program siaran jurnalistik (program yang berisi berita dan/atau informasi untuk ditujukan untuk kepentingan publik), harus memperhatikan prinsip-prinsip jurnalistik, diantaranya menerapkan prinsip praduga tak bersalah dalam peliputan dan/atau menyiarkan program siaran jurnalistik dan tidak melakukan penghakiman. ${ }^{13}$ Sehingga siaran langsung sidang pengadilan dalam program siaran jurnalistik, tidak boleh memberikan komentar yang sifatnya menghakimi ataupun melanggar prinsip praduga tak bersalah.

Pengaturan tentang siaran langsung, selain mengacu pada UU penyiaran dan P3/SPS, juga harus memperhatikan peraturan perundang-undangan lain yang berkaitan dengan proses persidangan. Inti dari proses persidangan adalah pembuktian. KUHAP tidak memberikan penjelasan mengenai pengertian pembuktian, KUHAP hanya memuat jenis-jenis alat bukti yang sah menurut hukum, yang tertuang dalam Pasal 184 ayat (1) KUHAP. Rusli Muhammad ${ }^{14}$ mengatakan bahwa pembuktian dalam hukum acara pidana diartikan sebagai suatu upaya mendapatkan keterangan-keterangan melalui alat-alat bukti dan barang bukti guna memperoleh suatu keyakinan atas benar tidaknya perbuatan pidana yang didakwakan serta dapat mengetahui ada tidaknya kesalahan pada diri terdakwa. Keterangan saksi merupakan alat bukti yang pertama yang disebut dalam KUHAP, pada umumnya tidak ada perkara yang luput dari pembuktian alat bukti keterangan saksi. Hampir semua pembuktian perkara pidana selalu bersandar kepada pemeriksaan keterangan saksi.

Prosedur pemeriksaan alat bukti saksi dalam KUHAP diatur dalam Pasal 160 ayat (1), yaitu: "Saksi dipanggil ke dalam ruang sidang seorang demi seorang menurut urutan yang dipandang sebaik-baiknya oleh hakim ketua sidang setelah mendengar pendapat penuntut umum, terdakwa atau penasihat hukum".

12 Pasal 33 - Pasal 39 P3/SPS KPI 2012

13 Pasal 40 P3/SPS KPI 2012

${ }^{14}$ Rusli Muhammad, Hukum Acara Pidana Kontemporer, Citra Aditya Bakti, Jakarta, 2000, dikutip oleh Dian Dewi Pulungsari dan Diyas Mareti Riswindani, "Analisis Yuridis Kekuatan Pembuktian Penilaian Hakim Tentang Keterangan Seorang Saksi Di Dalam Proses Peradilan Pidana Ditinjau Dari Kitab Undang-Undang Hukum Acara Pidana", Jurnal Verstek, Volume 3, Nomor 3, 2015, hlm. 2 
Selanjutnya Pasal 167 ayat (3) KUHAP mengatur bahwa : "Para saksi selama sidang dilarang saling bercakap-cakap."

Pengaturan prosedur pemeriksaan saksi sebagaimaan dalam Pasal 160 ayat (1) KUHAPdan Pasal 167 ayat (3) KUHAP menitikberatkan bahwa keterangan yang disampaikan oleh setiap saksi tidak bisa saling mengetahui. Artinya jika keterangan saksi sebelumnya disiarkan langsung media televisi, berpotensi untuk diketahui oleh saksi yang lain yang menyaksikan proses siaran langsung. Sehingga potensi untuk mempengaruhi keterangan saksi selanjutnya sangat tinggi.

Selain berbenturan dengan Pasal 160 ayat (1) dan Pasal 167, siaran langsung dapat melanggar hak-hak para saksi. Dalam praktiknya, siaran langsung proses persidangan seringkali tidak menghormati hak-hak saksi sebagaimana tertuang di dalam Undang-Undang Nomor 31 Tahun 2014 tentang Perlindungan Saksi dan Korban. Pasal 5 mengatur terkait hak saksi dan korban untuk dirahasiakan identitasnya. Pengungkapan identitas ke publik melalui siaran langsung tanpa ada sensor, berpotensi memberikan tekanan atau ancaman kepada saksi, baik oleh oknum tertentu maupun oleh opini massa. Sedangkan saksi, sebagaimana tertuang di dalam Pasal 5 ayat (1) huruf a berhak untuk mendapat perlindungan atas keamanan pribadi, keluarga, dan harta bendanya, serta bebas dari ancaman yang berkenaan dengan kesaksian yang akan, sedang atau telah diberikan.

Untuk mencegah hal-hal yang timbul terhadap efek dari penyiaran langsung jalannya proses persidangan kasus dugaan korupsi dalam pengadaan Kartu Tanda Penduduk berbasis elektronik (e-KTP) sebagaimana di Pengadilan Tipikor Jakarta Selatan. Ketua Pengadilan Negeri Jakarta Selatan menerbitkan Surat Keputusan Nomor 10 U1/KP 01.1.17505 XI201601, yang isinya bahwa proses persidangan meskipun terbuka untuk umum persidangan dilarang disiarkan langsung oleh media televisi. Terdapat tiga alasan larangan ini dilakukan ${ }^{15}$, yakni pertama majelis hakim ingin mengembalikan marwah pengadilan dimana pembatas ini bertujuan agar asumsi publik tidak berkembang sebelum hakim menjatuhkan putusan. Kedua, pengadilan tidak ingin menghancurkan konten persidangan dimana aktor-

15 “3 Alasan Pengadilan Larang Media Siarkan Sidang Live E-KTP” dalam https://nasional.tempo.co /read/854613/3-alasan-pengadilan-larang-media-siarkan-sidang-live-e-ktp diakses pada tanggal 30 April 2017 
aktor yang terlibat berpotensi merekayasa keterangan. Ketiga, peradilan adalah ranah personal, dimana pihak yang terlibat dalam proses peradilan tanpa diketahui publik pun telah menjadi beban keluarga, kerabat dan almamater.

Selain Pengadilan Negeri Jakarta Selatan, Pengadilan Negeri Jakarta Pusat melalui Surat Keputusan Ketua Pengadilan Negeri Jakarta Pusat Kelas 1A Khusus Nomor W10.U1/KP.01.1.17505XI.2016.01 juga melarang peliputan atau penyiaran persidangan secara langsung oleh media televisi di lingkungan PN Jakarta Pusat. Surat Keputusan Ketua Pengadilan Jakarta Selatan dan Jakarta Pusat dapat dimaknai untuk menjaga marwah pengadilan sebagai bentuk indepensi hakim dalam mengadili kasus tersebut, sehingga penayangan secara langsung jalannya proses persidangan oleh media televisi tidak diperkenankan lagi, namun televisi dan media massa tetap dapat meliput dan mengambil gambar di dalam ruang sidang. Artinya Pengadilan Negeri Jakarta Selatan maupun Jakarta Pusat hanya membatasi pada proses penyiaran secara langsung.

Uraian di atas menunjukkan bahwa pengaturan siaran langsung proses persidangan kasus pidana belum seragam. Dalam perspektif penyiaran, siaran langsung proses sidang diperbolehkan dengan beberapa syarat yang berkaitan dengan etika penyiaran dan jurnalistik. Akan tetapi, beberapa peraturan yang berkaitan dengan proses peradilan pidana akan sulit terlaksana apabila siaran langsung proses persidangan tetap dilakukan tanpa batas tertentu. Oleh karena itu, perlu pembatasan penyiaran secara langsung proses persidangan.

\section{Kajian terhadap Penerapan Asas Persidangan Terbuka Untuk Umum dalam Konteks Penyiaran Oleh Media}

Pelaksanaan hukum dalam kehidupan masyarakat sehari-hari mempunyai arti yang sangat penting karena apa yang menjadi tujuan hukum justru terletak pada pelaksanaan hukum itu. ${ }^{16}$ Sering terjadi perbedaan pandangan/pendapat para aparatur penegak hukum untuk menegakkan hukum dalam suatu kasus, sehingga hukum yang diterapkan mengandung kebenaran yang relatif, terkadang bersifat subjektif, baik dalam bidang penyidikan, penuntutan maupun proses di

\footnotetext{
${ }^{16}$ Livia V. Pelle, "Peranan Etika Profesi Hukum Terhadap Upaya Penegakan Hukum Di Indonesia", Jurnal Lex Crimen, Volume 1, Nomor 2, 2012, hlm. 27
} 
peradilan. ${ }^{17}$ Akibatnya masyarakat menjadi korban (victims). Praktik penegakan hukum di Indonesia sampai detik ini masih dililit oleh berbagai permasalahan yang menjauhkan hukum dari tujuan utamanya untuk memberikan keadilan, kepastian, dan kemanfaatan bagi masyarakat. ${ }^{18}$

Mekanisme peradilan dalam prosesnya mengadili dalam kenyataannya bukanlah proses yuridis semata. Proses peradilan bukan hanya proses menerapkan pasal-pasal dan bunyi undang-undang, melainkan proses yang melibatkan perilaku-perilaku masyarakat dan berlangsung dalam struktur sosial tertentu. ${ }^{19}$ Pelibatan media merupakan salah satu konsekuensi logis dari berkembangnya masyarakat di negara demokratis pada era digital seperti saat ini. Sehingga, tidak dapat dipungkiri, media mempunyai peran penting, bahkan pada proses berjalannya suatu kasus hingga proses peradilannya.

Revolusi media telah membawa perubahan dan perilaku masyarakat tidak saja dalam mengakses informasi namun juga dalam kegiatan menyebarluaskan informasi. ${ }^{20}$ Sehingga, pers mempunyai peranan sangat penting dalam negara demokrasi seperti Indonesia. Kemerdekaan pers sebagai hak asasi warga negara juga dijamin dalam UU Pers, sehingga dengan dalih apa pun pers harus bebas dari tindakan pencegahan, pelarangan dan atau penekanan agar hak masyarakat untuk memperoleh informasi terjamin. ${ }^{21}$ Pers dan media massa yang bebas untuk menyatakan pendapat merupakan salah nilai demokrasi yang perlu diselenggarakan di sebuah negara demokratis. ${ }^{22}$

Pers mempunyai kewenangan untuk mengadakan komentar terhadap jalannya peradilan, tetapi pemberitaan itu harus dengan penuh tanggung jawab dan mengedepankan asas praduga tak bersalah sehingga pemberitaan itu tidak merupakan rintangan bagi jalannya peradilan yang fair dan objektif. Kebebasan

\footnotetext{
${ }^{17}$ Ediwarman, "Paradoks Penegakan Hukum Pidana Dalam Perpektif Kriminologi Di Indonesia", Jurnal Kriminologi Indonesia, Volume 8, Nomor 1, 2012, hlm. 39

${ }^{18}$ Eman Suparman, "Menolak Mafia Peradilan: Menjaga Integritas Hakim Menyelaraskan Perbuatan dan Nuraninya", Jurnak Hukum dan Pembangunan", Volume 47, Nomor 1, 2017, hlm. 2

${ }_{19}$ Zainal Arifin Hoesein, "Lembaga Peradilan Dalam Perpektif Pembaharuan Hukum", Jurnal Media Hukum, Volume 20, Nomor 1, 2013, hlm. 24

${ }^{20}$ Manunggal K, et. al, "Revolusi Media, Jurnalisme Global, dan Hukum Pers Indonesia", Jurnal Dinamika Hukum, Volume 22, Nomor 2, 2011, hlm. 367-368

${ }^{21}$ Lihat Pasal 4 UU No. 40 Tahun 1999 tentang Pers

${ }^{22}$ Ni’matul Huda, Ilmu Negara, Cet. 7, Rajawali Press, Jakarta, 2015, hlm. 219
} 
dalam pemberitaan adalah kebebasan yang limitatif, yang dapat diwujudkan dalam ketentuan hukum, maupun yang merupakan suatu Zelf-oplegging, berupa moral/etika. Kebebasan ini tidak boleh mempengaruhi the fair administration of justice. ${ }^{23}$ Berarti, Arianti setuju agar yang dilakukan nantinya adalah fair trial melalui due process of law.

Siaran langsung secara kasat mata merupakan justifikasi dari penerapan asas persidangan terbuka untuk umum. Menurut Yahya Harahap, ${ }^{24}$ proses persidangan terbuka untuk umum bertujuan agar semua persidangan pengadilan jelas, terang dilihat dan diketahui masyarakat. Tidak boleh persidangan gelap dan bisik-bisik. Semua persidangan pengadilan terbuka untuk umum. Pada saat majelis hakim hendak membuka sidang, harus menyatakan "sidang terbuka untuk umum". Setiap orang yang hendak mengikuti jalannya persidangan, dapat hadir memasuki ruangan sidang. Pintu dan jendela ruangan sidang pun terbuka, sehingga dengan demikian makna asas persidangan terbuka untuk umum benar-benar tercapai. Terhadap hal tersebut, Yahya Harahap mengatakan dengan diperbolehkan masyarakat menghadiri persidangan pengadilan, jangan sampai kehadiran mereka mengganggu ketertiban jalannya persidangan karena setiap orang wajib menghormati martabat lembaga peradilan khususnya bagi orang yang berada di ruang sidang sewaktu persidangan sedang berlangsung. ${ }^{25}$

Sedangkan Moch. Faisal Salam, menafsirkan asas persidangan terbuka untuk umum sebagai jaminan bahwa hakim tidak berpihak. Bahwa setiap orang dapat menghadiri sidang tersebut, sehingga peradilan berada di bawah pengawasan pendapat umum. Tujuannya adalah agar hakim tidak menerapkan hukum secara sewenang-wenang ataupun dengan cara membeda-bedakan orang. ${ }^{26}$ Sehingga, asas persidangan terbuka untuk umum hakikatnya bertujuan sebagai bentuk pengawasan umum terhadap proses persidangan.

${ }^{23}$ Vivi Ariyanti, "Kebebasan Pers Dalam Perpektif Peradilan Pidana", Jurnal Dakwah dan Komunikasi, Volume 1, Nomor 1, 2010, hlm. 5

${ }^{24}$ Yahya Harahap, Pembahasan Permasalahan dan Penerapan KUHAP: Pemeriksaan Sidang Pengadilan, Banding, Kasasi, dan Peninjauan Kembali, Sinar Grafika, Jakarta, 2000, hlm. 110.

25 Ibid

${ }^{26}$ Moch. Faisal Salam, Hukum Acara Pidana dalam Teori dan Praktek, Cet. 1, Mandar Maju, Bandung, 2001, hlm. 273 
Kontrol ataupun pengawasan yang dilakukan oleh umum, tidak boleh mengganggu proses persidangan maupun menurunkan marwah pengadilan. Dalam siaran langsung sidang peradilan pidana tidak boleh menciderai prinsip lain dalam cakupan prinsip peradilan yang adil dan tidak memihak (fair trial).

Salah satu elemen penting dari prinsip peradilan yang adil dan tidak memihak (fair trial) berdasarkan Hak Asasi Manusia adalah asas praduga tak bersalah (the right to presumption of innocence). Asas praduga tak bersalah (presumption of innocence) merupakan salah satu hak asasi manusia yang fundamental untuk dilindungi. ${ }^{27}$ Menurut General Comment No. 32, asas praduga tak bersalah harus menjamin (terdakwa) agar tidak dilekatkan kesalahan sampai tuduhan tersebut terbukti tanpa keraguan. Asas ini mensyaratkan tidak adanya penghakiman (prejudging) sebelum ada putusan pengadilan. Selain itu, media juga harus menghindari liputan yang dapat menciderai asas praduga tak bersalah ini. ${ }^{28}$

Asas praduga tak bersalah sering dilanggar oleh media dalam siaran langsung liputan sidang pengadilan. Media seringkali menyajikan kasus hukum dimulai dengan siaran langsung proses sidang, kemudian membahasnya dalam sebuah diskusi bersama pakar maupun pihak-pihak yang berkepentingan, bahkan melakukan penelusuran terhadap kehidupan pribadi seseorang yang terlibat kasus tersebut. ${ }^{29}$ Siaran langsung proses persidangan selalu tidak pernah lepas dari komentar yang disajikan oleh program berita yang menayangkan. Asosiasi Jurnalis Indonesia (AJI) mengungkapkan, siaran langsung proses peradilan pidana tidak semata berisi siaran jalannya sidang, tapi juga diimbuhi dengan pandangan atau komentar pengamat dari pihak luar. Hal yang sama diungkapkan Dewan Pers, bahwa siaran langsung itu berisiko mengganggu independensi persidangan, sehingga mereka menghimbau siaran langsung itu tidak dilakukan. ${ }^{30}$

Sehingga, proses siaran langsung media televisi dikhawatirkan akan membangun opini publik, karena dengan masyarakat menyaksikan langsung

\footnotetext{
${ }^{27}$ Lihat Article 14, International Covenant on Civil and Political Rights yang telah diratifikasi dalam UndangUndang Nomor 12 Tahun 2005

${ }^{28}$ Lihat General Comment No. 32 Covenant on Civil and Political Rights, Article 14 Right to Equality before Courts and Tribunals and to a Fair Trial, para. 30

${ }^{29}$ Mosgan Situmorang dkk, Op. Cit., hlm. 29

30 "Sidang kasus Ahok: Perlukah siaran langsung televisi, mengapa?", dalam http://www.bbc.com/ indonesia/indonesia-38291620, diakses tanggal 29 April 2017.
} 
proses tahapan-tahapan persidangan, masyarakat dengan sendirinya membuat suatu pandangan dan bahkan kesimpulan terdakwa bersalah atau tidak sebelum adanya putusan hakim. Kondisi tersebut merupakan bentuk trial by press, yakni pers bertindak sebagai peradilan mencari bukti-bukti, menganalisa dan mengkaji sendiri untuk kemudian berakhir dengan memberi keputusan. ${ }^{31}$

Komisi Penyiaran Indonesia (KPI) pun memperingatkan bahwa dalam peliputan sidang pembacaan putusan media tidak boleh membentuk atau menggiring opini, lebih-lebih jika vonis berbeda dengan pengharapan publik. ${ }^{32}$ Kekhawatiran pun mulai ada ketika ekspektasi publik itu berbeda dengan putusan yang akan dikeluarkan. Biasnya adalah opini publik (sisi negatif) berbeda dengan pertimbangan hukum hakim dalam putusan. Namun demikian, barang tentu ada pula sisi positifnya. Misalnya, terlihat tata cara proses persidangan yang fair, sesuai dengan prinsip due process of law dan lain-lain.

Ide siaran langsung televisi atas sidang ini dilatari atas kesangsian persidangan suatu kasus bisa berjalan adil seperti yang dikhawatirkan para pihak pelapor. Namun belakangan, Dewan Pers menganggap siaran langsung itu berisiko mengganggu independensi persidangan, sehingga mereka meminta siaran langsung itu tidak dilakukan. Yosep Adi Prasetyo (Anggota Komisi Penyiaran) mengatakan proses siaran langsung sebaiknya tidak dilakukan, kecuali pada pembacaan dakwaan. Siaran langsung persidangan akan berpotensi pada kegaudahan di masyarakat dan akan membuat saksi-saksi tidak nyaman dalam memberikan keterangan. ${ }^{33}$

Pembatasan siaran langsung proses peradilan dicontohkan dalam putusan kasus P4 Radio Hele Norge ASA v. Norway di bawah Pengadilan HAM Eropa Eurupean Convention on Human Rights (ECHR) tentang peliputan media pada proses sidang kasus pidana di Norwegia. Dimana pihak P4 Radio Hele Norge ASA menggugat negara atas larangan penyiaran langsung sidang perkara pidana yang menjadi perhatian publik secara luas. Hakim Pengadilan HAM Eropa menyatakan bahwa siaran langsung di ruang sidang dapat mengubah karakteristiknya,

${ }^{31}$ Mosgan Situmorang, dkk., Op. Cit., hlm. 30

32 "Ekspektasi publik dikhawatirkan berbeda dengan putusan kasus Jessica Wongso" dalam http://www.bbc.com/indonesia/indonesia-37778944, diakses tanggal 30 April 2017.

33 "Sidang kasus Ahok: Perlukah siaran langsung televisi, mengapa?" Op. Cit. 
mendorong adanya tekanan tambahan bagi pihak-pihak yang terlibat dalam proses peradilan, bahkan terlalu banyak memberikan pengaruh bagaimana pihak-pihak tersebut bersikap, sehingga akan menimbulkan prasangka terhadap proses peradilan yang fair (adil). ${ }^{34}$ Pengadilan menilai bahwa siaran langsung proses persidangan biasanya tetap akan ada unsur penyaringan dan pilihan jurnalistik. ${ }^{35}$ Dengan adanya unsur pilihan jurnalistik dan penyaringan yang dilakukan oleh media, tentu saja akan membuat suatu kasus yang disiarkan media mempunyai muatan tertentu yang dapat mengarahkan opini massa.

Mantan Ketua Dewan Pers Bagir Manan mengatakan:

"Di banyak negara maju jarang terjadi proses persidangan dibuat terbuka dan bisa diakses secara bebas oleh media massa. Tradisi di negara-negara yang bebas sekalipun, apalagi negara tertutup, mereka tidak membiasakan keterbukaan sidang pengadilan. Mereka takut melanggar prinsip asas praduga tak bersalah. Peliputan yang sedemikian masif terhadap persidangan perkara dapat mengganggu kebebasan hakim. Kebebasan hakim yang merupakan kebebasan penegak hukum. Kebebasan hakim sangat absolut, untuk menegakkan keadilan dan kebenaran. Peliputan secara langsung, menurut Bagir juga dapat mempengaruhi terdakwa. ${ }^{36}$

Penulis menegaskan bahwa peran media televisi dalam menyiarkan siaran langsung proses peradilan tentunya harus lebih cermat dan mampu berimbang dalam melakukan pemberitaan. Termasuk juga menghormati proses peradilan dengan tidak membuat "peradilan tandingan". Media juga tidak boleh melakukan pemberitaan yang "dirasa" mampu menggiring opini yang nantinya akan mendahului putusan hakim. Oleh karena itu, dalam meliput suatu kasus, media harus dibatasi, terutama dalam hal siaran langsung. Hal ini bertujuan untuk melindungi kehormatan peradilan dan pihak-pihak yang terlibat dari segala bentuk trial by press.

\footnotetext{
34 Amelie Lepinard, "Media Reporting on Court Proceeding and the pan-European Human Rights Framework", IRIS Plus 2014-2 Media in the Courtroom, Council of Europe, hlm. 38

${ }^{35}$ Lihat The Court's Assessment dalam Third Section Decision as the Admissibility of Application No. 76682/01 by P4 RADIO HELE NORGE ASA v. Norway

36 "Dilema Siaran Langsung Televisi dalam Pengadilan Ahok", dalamhttp://www.suara.com/news /2016/12/09/202010/dilema-siaran-langsung-televisi-dalam-pengadilan-ahok, diakses tanggal 3 Mei 2016
} 


\section{Penutup}

Mendasari uraian pembahasan di atas, penulis dapat menyimpulkan sebagai berikut. Pertama, penyiaran langsung media televisi terhadap proses persidangan sesuai dengan Pasal 153 ayat (1) KUHAP. Dalam UU Penyiaran dan peraturan teknis, tidak ada larangan siaran langsung proses persidangan sepanjang memenuhi syarat etika penyiaran dan jurnalistik. Akan tetapi, penyiaran secara langsung proses persidangan tetap harus dibatasi agar tidak melanggar hak-hak terdakwa, saksi maupun korban sebagaimana diatur dalam UU Perlindungan Saksi dan Korban. Selain itu, pembatasan proses siaran langsung juga bertujuan untuk menjaga kelancaran proses persidangan serta marwah independensi pengadilan dalam mengadili suatu perkara. Kedua, penerapan asas persidangan terbuka untuk umum dalam konteks penyiaran oleh media tidak boleh melanggar asas praduga tak bersalah. Selain itu, siaran langsung yang dilakukan oleh media sangat rentan menyebabkan trial by press. Oleh karena itu, untuk mewujudukan prinsip peradilan yang adil dan tidak memihak (fair trial), siaran langsung dalam proses peradilan pidana harus dibatasi.

Dengan demikian, penulis memberikan rekomendasi kepada media, untuk tidak menggiring opini massa ataupun memberikan penghakiman sebelum adanya putusan hakim selama peliputan suatu kasus. Hal ini demi mencegah adanya trial by press dan mewujudkan asas praduga tak bersalah serta prinsip peradilan yang adil dan tidak memihak (fair trial). Kepada Mahkamah Agung merumuskan dan mengesahkan peraturan yang berkaitan dengan penyiaran sidang pidana oleh media.

\section{Daftar Pustaka}

\section{Buku}

Harahap, Machyudin Agung, Kapitalisme Media; Ekonomi Politik Berita dan Diskursus Televisi, Aura Pustaka, Yogyakarta, 2013.

Harahap, Yahya, Pembahasan Permasalahan dan Penerapan KUHAP: Pemeriksaan Sidang Pengadilan, Banding, Kasasi, dan Peninjauan Kembali, Sinar Grafika, Jakarta, 2000.

Huda, Ni'matul, Ilmu Negara, Cet. 7, Rajawali Press, Jakarta, 2015. 
Muhammad, Rusli, Hukum Acara Pidana Kontemporer, Citra Aditya Bakti, Jakarta, 2000.

Salam, Moch. Faisal, Hukum Acara Pidana Dalam Teori dan Praktek, Mandar Maju, Bandung, 2001

\section{Jurnal}

Ali, Mahrus, "Sistem Peradilan Pidana Progresif; Alternatif Dalam Penegakan Hukum Pidana". Jurnal Ius Quia Iustum, Volume 14, Nomor 2, 2007.

Amdani, Yusi, "Implikasi Penafsiran Undang-Undang Oleh Hakim Praperadilan Dalam Perkara Tindak Pidana Korupsi", Jurnal Mimbar Hukum, Volume 27, Nomor 2, 2015.

Avriyanti, Vivi "Kebebasan Pers Dalam Perpektif Peradilan Pidana", Jurnal Dakwah dan Komunikasi, Volume 1, Nomor 1, 2010.

Borgida, Eugene, et.al, "Cameras in the Courtroom: The Effects of Media Coverage on Witness Testimony and Juror Perceptions" Law and Human Behavior, Volume 14, Nomor 2, 1990.

Djanggih, Hardianto dan Yusuf Saefudin, "Pertimbangan Hakim pada Putusan Praperadilan: Studi Putusan Nomor: 09/PID. PRA/2016/PN. Lwk Tentang Penghentian Penyidikan Tindak Pidana Politik Uang". Jurnal Penelitian Hukum De Jure, Volume 17, Nomor 32013.

Ediwarman, "Paradoks Penegakan Hukum Pidana Dalam Perpektif Kriminologi Di Indonesia", Jurnal Kriminologi Indonesia, Volume 8, Nomor 1, 2012.

Hoesein, Zainal Arifin, "Lembaga Peradilan Dalam Perpektif Pembaharuan Hukum", Jurnal Media Hukum, Volume 20, Nomor 1, 2013.

K. Manunggal, et. al, "Revolusi Media, Jurnalisme Global, dan Hukum Pers Indonesia", Jurnal Dinamika Hukum, Volume 22, Nomor 2, 2011.

Kasengkang, Feibe A, "Kewenangan Komisi Penyiaran Indonesia Tentang Persyaratan Program Isi Siaran Menurur Undang-Undang Nomor 32 Tahun 2002", Jurnal Lex Privatum, Volume 5, Nomor 3, 2017.

Kriyantono, Rachmat,"Pemberdayaan Konsumen Televisi Melalui Ketrampilan Medialiteracy Dan Penegakan Regulasi Penyiaran" Jurnal Penelitian Komunikasi, Media Massa dan Teknologi Informasi, Volume 10, Nomor 2, 2017.

Lepinard, Amelie, "Media Reporting on Court Proceeding and the pan-European Human Rights Framework", IRIS Plus 2014-2 Media in the Courtroom, Council of Europe.

Pelle, Livia V, "Peranan Etika Profesi Hukum Terhadap Upaya Penegakan Hukum Di Indonesia", Jurnal Lex Crimen, Volume 1, Nomor 2, 2012.

Pulungsai, Dian Dewi dan Diyas Mareti Riswindani, "Analisis Yuridis Kekuatan Pembuktian Penilaian Hakim Tentang Keterangan Seorang Saksi Di Dalam 
Proses Peradilan Pidana Ditinjau Dari Kitab Undang-Undang Hukum Acara Pidana", Jurnal Verstek, Volume 3, Nomor 3, 2015.

Sertyanegara, Eri, "Kebebasan Hakim Memutus Perkara Dalam Konteks Pancasila (Ditinjau Dari Keadilan "Substantf")", Jurnal Hukum dan Pembangunan, Volume 44, Nomor 4, 2013.

Suparman, Eman, "Menolak Mafia Peradilan: Menjaga Integritas Hakim Menyelaraskan Perbuatan dan Nuraninya", Jurnal Hukum dan Pembangunan", Volume 47, Nomor 1, 2017.

\section{Internet}

"3 Alasan Pengadilan Larang Media Siarkan Sidang Live E-KTP” dalam https:/ / nasional.tempo.co/read/854613/3-alasan-pengadilan-larangmedia-siarkan-sidang-live-e-ktp diakses pada tanggal 30 April 2017.

"Dilema Siaran Langsung Televisi dalam Pengadilan Ahok", dalam http:/ / www.suara.com/news/2016/12/09/202010/dilema-siaranlangsung-televisi-dalam-pengadilan-ahok, diakses tanggal 3 Mei 2017.

"Ekspektasi publik dikhawatirkan berbeda dengan putusan kasus Jessica Wongso" dalam http://www.bbc.com/indonesia/indonesia-37778944, (diakses tanggal 30 April 2017).

Linder, Douglas, "The Trial of Orenthal James Simpson (2008). Available at SSRN: https:/ / ssrn.com/abstract=1305244 or http:/ / dx.doi.org/10.2139/ ssrn.1305244.

"Sidang kasus Ahok: Perlukah Siaran Langsung Televisi, Mengapa?" dalam http:/ / www.bbc.com/indonesia/indonesia-38291620, (diakses tanggal 29 April 2017).

Situmorang, Mosgan dkk, "Penelitian Hukum tentang Pengaruh Praktir Courtroom Television Terhadap Independensi Peradilan", Badan Pembinaan Hukum nasional Kementrian Hukum dan HAM RI, 2013 http://www.bphn.go.id/data/documents/laphir_integrasi_cetak.pdf

Putusan Pengadilan akan Terbuka untuk Umum http:/ / www.hukumonline.com/berita/baca/hol8500/putusanpengadilan-akan-terbuka-untuk-umum diakses pada tanggal 3 Mei 2017

\section{Kovenan Internasional}

International Covenant on Civil and Political Rights

General Comment No. 32 Covenant on Civil and Political Rights Article 14 Right to Equality before Court and Tribunal and to a Fair Trial

\section{Putusan Pengadilan}

Putusan Pengadilan HAM Eropa (ECHR) Application No. 76682/01 by P4 RADIO HELE NORGE ASA v. Norway 


\section{Peraturan Perundang-Undangan}

Undang-Undang Dasar Negara Republik Indonesia Tahun 1945

Undang-Undang Nomor 8 Tahun 1981 Tentang Hukum Acara Pidana (Tambahan Lembaran Negara Republik Indonesia Nomor 3258)

Undang-Undang Nomor 40 Tahun 1999 tentang Pers (Tambahan Lembaran Negara Republik Indonesia Nomor 3887)

Undang-Undang Nomor 32 Tahun 2002 Tentang Penyiaran (Tambahan Lembaran Negara Republik Indonesia Nomor 4252)

Undang-Undang Nomor 12 Tahun 2005 tentang Pengesahan Covenant and Civil and Political Rights (Kovenan tentang Hak-hak Sipil dan Politik) (Tambahan Lembaran Negara Republik Indonesia Nomor 4558)

Undang-Undang Nomor 48 Tahun 2009 Tentang Kekuasaan Kehakiman, (Lembaran Negara Republik Indonesia Tahun 2009 Nomor 157)

Undang-Undang Nomor 31 Tahun 2014 tentang Perlindungan Saksi dan Korban (Tambahan Lembaran Negara Republik Indonesia Nomor 5602) 